\title{
Lalo'a: Traditional Conservation Of Boronang Fish In Liya Indigenous Communities
}

\author{
Sumiman Udu \\ \{sumimanudu@uho.ac.id\} \\ Universitas Halu Oleo Kendari, Sulawesi Selatan, Indonesia
}

\begin{abstract}
This research aims at examining the traditional conservation of Boronang fish management as one of the local wisdoms of the Kadhia Liya, indigenous people of Wakatobi district. Through their local wisdom, they can protect the lalo'a season or through the fish stocks in the Wakatobi community. This research was conducted using an ethnographic approach, so data collection and processing is carried out with ethnographic principles. Data collection was conducted using observation, in-depth interview, and documentation to understand how the perspective of the local community in seeing the journey of the boronang passing through the customary territory of Kadhia Liya. The results of this study indicated that in the management of fish migrating in the Sempo region, get protection from the indigenous Liya people. They forbid fishing when they have not laid eggs yet. The Liya people know the date of each year and the natural signs so that they can protect the passing boronang fish in their customary territory. As a result of this conservation concept, the Liya people have a lot of boronang fish each year, because their area is a safe place for spawning boronang fish. They also give sanctions to the people who disrupt the laying period of boronang fish, and the Liya people will release boronang fish that still have eggs in their stomachs. They will wait until the fish have laid eggs before they can be caught. Currently the Kadhia Liya indigenous people, determine lalo'a as one of the cultural attractions in the development of tourism in their village.
\end{abstract}

Keywords-Lalo'a, conservation, indigenous people, kadhia, Liya

\section{Introduction}

Indonesia is a cultural super power country. Every culture has local wisdom in managing its environment [1], [2]. This is as that environmental wisdom can be realized in social values, customary norms, ethics, belief systems, traditional spatial planning patterns, as well as environmentally friendly equipment and simple technologies. Social resources inherited from generation to generation, in fact proven to be effective in preserving the environment, and ensuring the preservation of the social environment. Thus, local wisdom lalo'a is one of the social values, customary norms, ethics, belief systems, traditional spatial planning patterns, and 
simple environmentally friendly equipment and technology owned by the Liya indigenous people in environmental management, especially those related to the environment.

Thamrin said that within the local community, local wisdom manifests itself in the form of a set of rules, knowledge, as well as the skills and values and ethics that govern the social order of the community that continues to live and develop from generation to generation. As one of the Kadhia Liya indigenous peoples' systems, lalo'a is a form of traditional wisdom or local wisdom of the Kadhia Liya indigenous people in the form of a set of rules, knowledge, and also the skills and values and ethics that govern the social order of the community that lives on and develop from generation to generation.

Referring to the above thought, it is necessary to explain the concept of local wisdom. For that reason, the term local wisdom (local wisdom) is a word that consists of the words "wisdom" (wisdom) and local (local). In general, local wisdom (local wisdom) can be understood as local ideas and values (local) that are wise, full of wisdom, good value, embedded and followed by members of the community [3]. Anthropology, familiar with the term local genius, was first introduced by Quaritch Wales. Cultural experts discuss the definition of local genius, such as Haryati Soebadio who said that local genius is also cultural identity, national cultural identity/personality that causes the nation to be able to absorb and process foreign cultures according to their own character and abilities [3], [4]; The lalo'a tradition, is a custom basically tested naturally and undoubtedly of good value, because the habit is a repetitive and reinforced social act.

To better understand the Kadhia Liya indigenous community-based resource management system, this research was conducted using the ethnographic paradigm. Ethnography is one of the more research models related to anthropology, which studies cultural events, which present a view of the subject of life that is the object of research [5]. Furthermore, ethnography has been developed into one of the social science research models that actually uses the philosophical foundation of phenomenology [6]. Ethnography, both as a research report and as a research method, can be considered as the basis and origin of anthropology. To get data on the lalo'a tradition, a field research method is needed using ethnography of one approach.

Thus, this research was conducted with ethnographic principles, so that it can illustrate how the indigenous peoples of Kadhia Liya see the lalo'a tradition as one of local wisdom in an effort to conserve their local resources. The data in this study will also be carried out with ethnographic principles, so that it can describe the world view of Kadhia Liya indigenous peoples in managing their resources. Of course, the concept of emics and ethics will make this article one of the articles that can save the concept of indigenous community-based Kadhia Liya resource management

\section{Method}

This research employs ethnographic approaches as qualitative descriptive analysis. This research therefore utilizes ethnographic principles. Observation, in-depth interviews and documentation were used to collect data. Observations were made to find out how baronang fish are maintained, preserved and managed by the Wakatobi District Liya people. Interviews were conducted to dig deeper information on how to manage baronang fish in their marine waters from the perspective of the community. Traditional leaders, community leaders, and fishermen in the Liya sea waters were interviewed. Data analysis was conducted by classifying data, reducing data, analyzing data and drawing conclusions. 


\section{Results and Discussion}

\subsection{Laloa as the Kadhia Liya Indigenous Community Based Resource Management Concept}

The indigenous Kadhia Liya people have a lot of local wisdom in resource management. Some local wisdom in the management of these resources, is the management of padangkuku (savanah fields), motika (forest), springs, sea, coral, and fish management [7]. In marine fish management, the Kadhia Wanse indigenous community has the concept of resource management by limiting exploitation as it applies to menami fish or Napoleon fish (Cheilinus undulates). They call Menami fish as ika nu sara or fish that are only intended for traditional institutions. After researching, menami or napoleon is a very tasty type of fish, so that many people like Wakatobi. At present, the world population is also very many who order this fish. This is as said by Ricky when interviewed by Dani Jelius Zebua who said that napoleon fish was much requested by China and Hong Kong, so that its development was very limited. With this local wisdom concept based on the sara kadhia Liya custom, the sustainability of Napoleon fish can be maintained in the reefs of Wakatobi. Especially now, napoleon is a form of fish that is expensive. The concept of local wisdom provides sustainable protection from the indigenous Liya people and other indigenous peoples in Wakatobi.

Another aspect of local wisdom is the existence of customary rules for not taking various shells whose shells are not yet perfect. They also forbid to take the shells that have not been perfect shell. With this prohibition, the Liya indigenous people and most of the Wakatobi indigenous people provide protection to their resources in the form of shells. They also provide protection to other resources such as communally managed ground water, so that everyone can access water resources. It's just that there are some resources that are specifically for the sara. The concept of resource management by indigenous peoples is very important for sustainable development in Wakatobi [7]. Lalo'a is one of the local conservation models based on the customary Kadhia Liya community that provides protection to Borona or Baronang fish that come to the beach (seagrass area) to lay their eggs. Understanding the behavior of baronang fish that come to lay their eggs every 15 th of September in September, the indigenous Kadhia Liya people take protection by not allowing people to catch bhorona or Baronang that have not yet laid eggs. This customary ban has an impact on the behavior of baronang fish that come every year to shallow waters on the customary Kadhia Liya coast especially around the sempora. For the Liya indigenous people, the lalo'a tradition also limits the people who will come to catch fish in a funnel or net. Prohibition is also applied to mothers who are pregnant, including their husband and wife who are still pregnant.

For the Liya indigenous people, people can catch fish during the season of Borona Fish eggs are only parika or fish handler. They are allowed to catch fish in the pit. The concept of the prohibition like this can also be found in several regions in Indonesia such as the prohibition of the exploitation of sea products known as sasi in the Maluku and Papua Region as said by Zulfikar Judge and Mariska Nurizka, entitled The Role of Sasi Laut Customary Law in Protecting Environmental Sustainability in the Village of Eti Regency Seram Barat Barat (2008) which provides protection against shellfish, seaweed, sea cucumbers and others is usually subject to sasi, because it is considered important and valuable by the local community. This is the same as what is done by the indigenous Kadhia Liya people in the lalo'a tradition, where they protect the eggs of the boronang fish that will lay eggs. While in the customary area of Kadhia Wanse, taking sea urchins and shells using sacks is also strictly prohibited. 
In Buton culture in general, it is believed that in order to guard against pigs or caterpillar pests, a ban on entry into the garden for women who are menstruating is also enforced. Even at one time La Niampe, said that "When the garden that grows without being fenced off, and the corn can grow without being disturbed by pigs. However, after harvesting, where students' children enter the garden to harvest corn, the next day almost all of the corn was damaged by pigs. Seeing the issue, La Niampe said that "It is possible that a menstruating woman entered the garden yesterday. As a result, all corn is eaten by pigs. Of course, this kind of understanding also affects the beliefs of Kadhia Liya indigenous people. They certainly have the belief that fish that are laying eggs should not be faced with the condition of women who are menstruating. The same thing was said by Wa Bata, that his garden yields were not many this year, because he often found pads in his garden.

Through the lalo'a tradition, the Kadhia Liya indigenous community protects fish that have not laid eggs yet. This wisdom contributes to environmental management in the Wakatobi community. However, after the fish lay eggs, they can catch these fish. in modern society, Wonosobo Regency has provided protection for fish by issuing policies in the form of Wonosobo District Regulation No. 28/2002 [8] concerning protection of fish. This shows that lalo'a as a form of local wisdom can be developed into one of the regional regulations in the management of fish and sea in Wakatobi. With the tradition of lalo'a, the Kadhia Liya indigenous people are able to protect the fish resources (boronang eggs) in their customary territories. They can protect the movement of boronang fish that come to lay eggs. The local wisdom of this community is a form of conservation of indigenous peoples in environmental management within the indigenous Kadhia Liya community. This concept can be the strength of community-based tourism development that is able to develop sustainable resources. In addition, the concept of indigenous community-based resource management is a form of cultural commitment in the development of sustainable fisheries that must continue to be developed into the future.

\subsection{Laloa in the Context of Sustainable Tourism Development}

Local knowledge of lalo'a can be transformed in the form of cultural attractions that support the development of traditional Liya tourism villages. As one of the tourism products that can be sold, the Liya Kadhia community develops the lalo'a tradition into a lalo'a festival. In this event, the lalo'a tradition is made as one of the cultural attractions planned to be set as an annual event for the Liya people. In the first lalo'a festival held on 11-13 October 2019, the Liya Kadhia community developed several events, such as: (1) lalo'a parade, (2) hekansira, (3) boronang fuel, (4) until, (5) seaweed noodle sesansi, (6) hekomba'a, (7) mariga honari, (8) mangani'a. From some of these activities, festival activities were closed with fish adoption activities. While Saleh Hanan as one of the environmentalists who is also the son of Liya said that "The Liya community waits, welcomes, encourages them, and takes care of them, is a form of glorifying our guests. Every lalo'a season, we have guests that we glorify namely baronang fish that we treat wisely. That is why parika, customary leaders in fisheries governance, especially in the tradition of lalo'a in the Kadie Liya indigenous community, plays a role in examining the intentions, behavior, in the procession of lalo'a, as well as signals of harmony in nature and humans".

The concept of local wisdom lalo'a transformation in the form of tourism provides space for the world community to understand the local wisdom of indigenous peoples of Kadhia Liya in resource management. With lalo'a festival packaging, it can provide four important aspects of sustainable tourism, namely: 1) sustainable environmental management, (2) sustainable sociocultural, (3) sustainable economy, and (4) sustainable governance as expected in the concept 
sustainable tourism development carried out by the ministry of tourism. Lalo'a festival, introducing lalo'a traditions to the world to understand how the hospitality of the Liya Kadhia community in managing resources. Lalo'a as one of the traditions of waiting or keeping Boronang fish from being disturbed by fishermen before laying eggs. Bali where tourists and world leaders will come to see the reefs they adopted. While in the concept of lalo'a, an adapter will be able to watch the boronang fishes they adopt in the coming years, where the fish eggs they adopt this year will be the parent for their eggs to be adopted again the following year. In coral conservation in Pemuteran village, making an innovation, namely opening donations or direct transfers to adopt coral reefs [9]. Adapters will always be invited to come to see the coral reefs every year. The concept of lalo'a like this, also occurs in various regions in Wakatobi, but not all community groups protect fish eggs that occur at certain seasons like this. For example, in the 1990s, Longa villagers interfered with bhete or tembang fish when it came to BungiBungi to lay eggs. Another aspect that can be developed is the aspect of governance of the lalo'a tradition. If before the management of the lalo'a tradition was only based on indigenous peoples, then with the festival, the lalo'a tradition had involved the administration of the administrative villages in the Liya Kadhia region. In addition, in governance, the involvement of the Wakatobi National Park, as well as NGOs such as WWF and Swiss Contact Wakatobi have given strength in managing the lalo'a tradition as a conservation space for indigenous peoples-based resources. It is expected that in the future, several universities in the Region such as the Muslim University of Buton and Halu Oleo University are already interested in conducting research on local traditions in the management of indigenous community-based resources. This is like the involvement of Halu Oleo students in the lalo'a tradition which was held on October 11-13, 2019.

Thus, the management of the lalo'a festival in the context of tourism can be an important part of sustainable tourism-based resource management. This concept can make a positive contribution to four aspects of sustainable governance, namely sustainable environment, sustainable socio-cultural, sustainable economy and sustainable governance. The increased participation of indigenous Liya and Maupu Kadhia international communities in adopting Boronang fish, has contributed to the increasing awareness of indigenous Liya communities in environmental management.

\section{Conclusion}

The lalo'a tradition is one of the legacies of the Liya indigenous people in sustainable resource management. Through this tradition, they can provide opportunities for Boronang to lay eggs every year. Through this tradition, the Kadhia Liya indigenous people can inherit a sustainable fisheries resource management system to the younger generation, both to the Kadhia Liya indigenous people and to the young generation throughout the world. The concept of sustainable fisheries has made an important contribution in the management of sustainable tourism. Through the lalo'a festival as one of the developments of indigenous community-based tourism, lalo'a can contribute to the management of sustainable resources, sustainable sociocultural, sustainable economy and also sustainable governance. Hopefully in the future, the development of the tradition of lalo'a in increasing the interest of the global community to adopt baronang fish, so that it can have a quite wide impact in the management of indigenous community-based resources. This concept can be one of the events that can be set as one of the event calendars in Wakatobi tourism and even Indonesia. 


\section{References}

[1] P. Hijjang, A. Ismail, A. Marhadi, S. A. K. Frank, F. Sokoy, and U. Idris, "Puyakhabhu: Local Wisdom Values In Environmental Management At Sentani Indigenous Community In Jayapura Regency, Papua," Int. J. Arts Sci., vol. 11, no. 1, pp. 59-66, 2018.

[2] D. Kartikawangi, "Symbolic convergence of local wisdom in cross-cultural collaborative social responsibility: Indonesian case,” Public Relat. Rev., vol. 43, no. 1, pp. 35-45, 2017.

[3] S. Sartini, "Menggali Kearifan Lokal Nusantara: Sebuah Kajian Filsafati," J. Filsafat Univ. Gadjah Mada, vol. 14, no. 2, 2004.

[4] Ayatrohaedi, Personality Cultural Nation (local Genius). Jakarta: Reader Jaya, 1986.

[5] M. Siddiq and H. Salama, "Etnografi Sebagai Teori Dan Metode," Kordinat J. Komun. Antar Perguru. Tinggi Agama Islam, vol. 18, no. 1, 2019.

[6] N. Muhadjir, Qualitative Research Methodology. Positivistic, Rationalistic, Phenomenological Approaches and Metaphysical Realism Study of Text Study and Religious Research. Jakarta: Rake Sarasin, 1996.

[7] S. Udu, "Pengembangan Pariwisata Dan Hilangnya Tanah-Tanah Sara Di Wakatobi: Kajian Atas Perlawanan Masyarakat Adat," in Prosiding The 4th International Conference on Indonesian Studies: "Unity, Diversity and Future," 2012.

[8] "Wonosobo Regency Regulation Nomor 28 concerning Protection of Fish," 2002.

[9] I. K. S. Diarta, "Community Basic Tourism in the Development of Ecotourism in Coral Reefs in Pemuteran in the book," in Model Community Based Tourism Bali, Denpasar: Study Program Masters in Tourism Studies, 2015. 